\title{
Has the Special Economic Zone Approach Improve Ghana's Competitiveness in the Global Market?
}

\author{
Kutin-Mensah Florence \\ School of Business, Hohai University, Nanjing, 210098, China \\ Institute of Industrial Economics, Hohai University, Nanjing, China \\ E-mail: flokumens@yahoo.com
}

Dechun Huang

School of Business, Hohai University, Nanjing, 210098, China

Institute of Industrial Economics, Hohai University, Nanjing, China

\section{Boateng Ofosu Richard}

School of Public Administration, Hohai University, Nanjing, 210098, China

Chiponga Rutendo

School of Business, Hohai University, Nanjing, 210098, China

Received: May 1, 2017 Accepted: June 5, 2017

doi:10.5296/ber.v7i2.11142 URL: https://doi.org/10.5296/ber.v7i2.11142

\begin{abstract}
Ghana adopted the Special Economic Zones (SEZs) model in an attempt to stimulate economic growth by moving from an era of import-based to an export-based development strategy and also to potentially improve competiveness in the world market. However, until now, it is not well understood if this move has been beneficial and whether it has positioned Ghana particularly in terms of trade on the global market. This study examines and demonstrate if the adopted SEZ model has had any significant effects on the trade patterns in Ghana. This was undertaken by analyzing the competiveness and the dynamics and/or level of comparative advantage of selected products traded within the SEZs on sectoral levels in the world market using the Balassa Revealed Comparative Advantage (RCA) index. The
\end{abstract}


results shows that among the investigated products, Ghana shows little and/or no comparative advantage for manufactured goods with a maintained relative competiveness for raw materials. In addition, the RCA index indicates that Ghana has not improved its competiveness even in the exports of its resource intensive products such as Wood and Minerals. Clearly, it was revealed that Ghana appears to not have made any substantial progress towards taking advantage of the dynamic potential of SEZs as a tool for sustainable exports gains transformation. In the light of the evidence shown, some policy implications and recommendation are described.

Keywords: Ghana, Special Economic Zones, Revealed Comparative Advantage, Trade, Export patterns, Free zones

\section{Introduction}

In the last few decades of globalization, most developing countries are seeing a shift from an era of importing based development strategy to one based on export promoting approaches by creating special economic zones (SEZs) within its national borders Litwack and Qian (1998);(Aggarwal et al., 2008). SEZs are used to stimulate private investment and economic development through preferential government policies (Farole, 2011). It has been demonstrated to have the potential to be an effective mechanism to promote industrialization as noted in participating countries especially in the East Asia (Zeng, 2015). This has attracted many countries especially developing nations to implement this approach with the key objective of enhancing the competitiveness to deliver economic turnaround.

Whiles some countries such as China, Singapore have demonstrated successful implementation with notable advancement in their economy (Zeng, 2015), most participating developing countries still lag especially those in Sub-Sahara Africa (Farole, 2011). Most of these countries until now are still not able to compete and integrate into the global trade platform that produce the goods and services that are demanded by consumers around the world. Ghana is no exception to the numerous sub-Sahara Africa countries that have not been successful (Chalfin, 2001).

In the early 90s, Ghana adopted the free zone model as an economic policy tool with the aim of reversing the decades of economic failures since independence from British colonization (Angko, 2014). With this, it was expected that both GDP and export will grow as well as a perceived declination in poverty. Furthermore, it was argued this move could potentially improve Ghana's competiveness in the world market. However, Ghana has not realized the intended impact of the SEZ on its economy and other expectations have not been met. Albeit some relative improvement that has been seen over the last few years, Ghana's SEZ experience has not been anywhere near as successful as policy makers hoped it would be (Angko, 2014). Ghana is one of the very few Africa nation that has been asserted to be a promising candidate for SEZ reform which was highlighted by World Bank report describing Ghana's SEZ program as "one of the best designed, most flexible and most innovative in Africa" (Moberg and Tarko, 2014). This therefore raises questions as to why Ghana after many years of establishing SEZs still trial in developing the model to become an important policy tool to drive substantial economic returns. 


\section{MInstitute ${ }_{\text {Int" }}^{\text {Macrothink }}$}

Business and Economic Research

ISSN 2162-4860

2017, Vol. 7, No. 2

The establishment of the SEZ has brought about a characterised geographically dispersed rapid market-driven changes providing opportunities for trade and export of products by industries in Ghana. With liberation in trade and improvements in exports with strong international competiveness being one of the key highlight for establishing the SEZ's, this study therefore aims to examine the export patterns and dynamics especially after the establishment of the SEZ. This effort is to provide valuable insights of comparative advantage and/ or competiveness of key products traded within the zones. This was explored by using the Revealed Comparative Advantage (RCA) index concept by (Balassa, 1965, 1977; Balassa \& Noland, 1989). The approach with the RCA index model was to computes by product export categories based on Standard International Trade Classification (SITC) by the World Trade Organization for listing products. To provide a global perspective the export competiveness and comparative advantage of Ghana in the world market, this study compared Ghana's competiveness with China. The reason for comparison with China is because of the increasing importance of China as a powerhouse in global trade as well as the significant trade patterns and differences between China and Ghana. Thus in this study, we analyzed the RCA of selected key export products of Ghana to investigate:

i. Has the establishment of the free trade zone model enhanced Ghana's export comparative advantage patterns and competiveness in the world market?

ii. What has been the temporal shift in the RCA of these selected products before and after the adoption of the SEZ model?

iii. Which of the key products have prominently improved revealed comparative advantage in the world market?

It is expected that this study will contribute to the existing gap literature and drive knowledge on competitiveness of Ghana's export sector in relation to the global market as well as propel further studies to better our understanding on the driving factors for the observed stillness in Ghana's SEZ economic contribution.

\section{Ghana Export Overview}

The poor economic performance of most countries in Sub-Sahara Africa has been linked to the low growth of exports in general and particularly manufactured exports (Söderbom \& Teal, 2003). As with many other Africa countries and other developing countries elsewhere, Ghana sees the development of SEZ as a vital component to facilitate private sector investment and promote export-oriented growth and generate employment. The economy of Ghana is reported to be much more successful before her independence in 1957 than has the trend been since (Teal, 2002) (Figure 1). Ghana's openness to the global economy at the beginning of the twentieth century during the post colonization by the British changed the country from just a subsistence economy driven by survival to live to relatively well-to-do people. Figure 1 shows the rise and decline of Ghana's per capita exports (measured in US\$). As shown, the trend decreased by the late $20^{\text {th }}$ century $(1960-1990)$ after Ghana's independence. This has been reported to be as a result of the ruling government instability during this period as well as failure of policy to provide for macroeconomic stability and the lack of technical progress in the economy (Leith, 1996). However, by the end of the $20^{\text {th }}$ 
century, Ghana's exports reverted to the level similar to the beginning to which the establishment of the SEZ was reported to be a key catalyst. Nevertheless, its share in the global market had been in decline contrary to the early part of the century where it experienced a sharp rise.

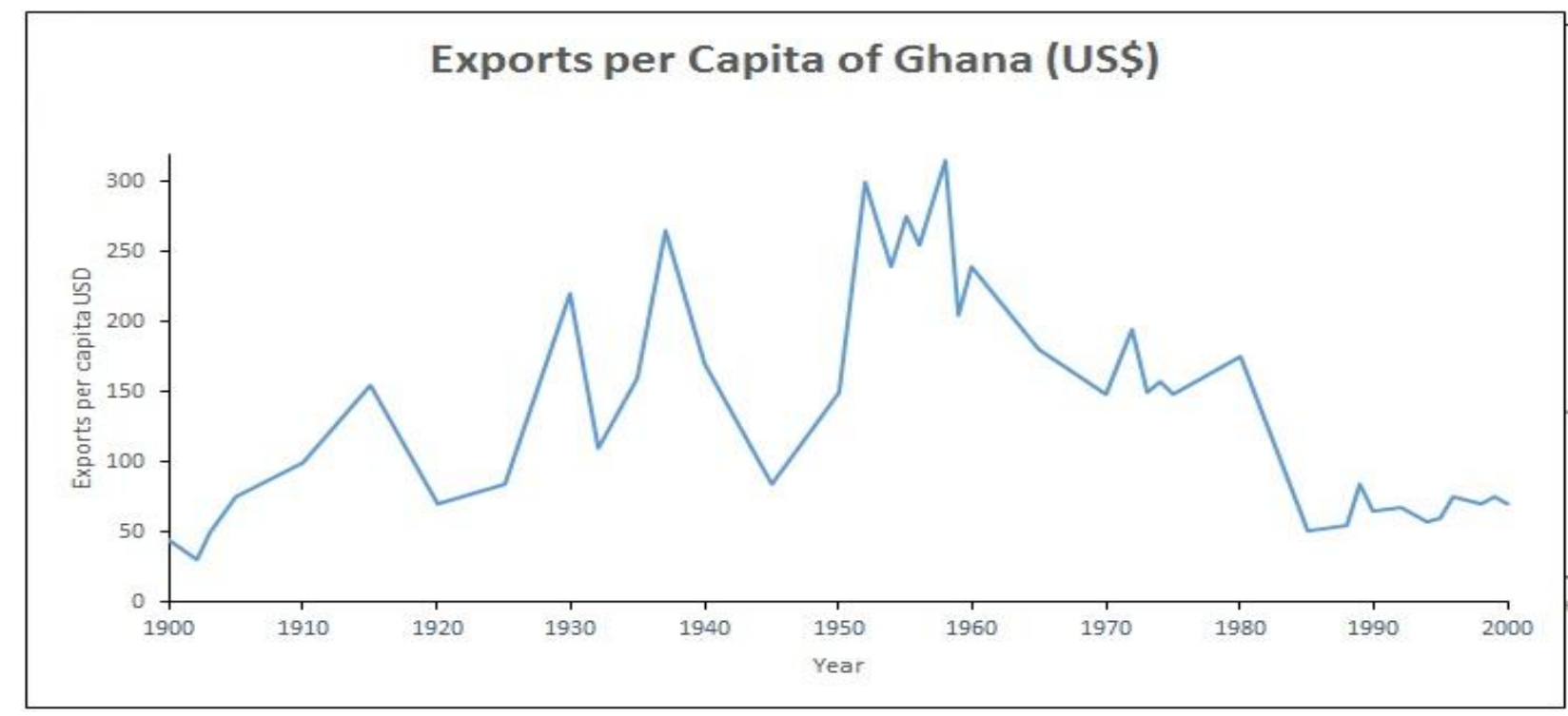

Figure 1. Ghana's Annual export per capita value in the $20^{\text {th }}$ century of total exports

Ghana is recognized as one of the largest economies within the Economic Community of West African States (ECOWAS). However, it is often argued that Ghana's economy have endured the long-term declines in the terms of trade they have encountered (Teal, 2002). As of 2015 , Ghana had a negative trade balance of $\$ 3.28$ billion in net imports as compared to their trade balance in 1995 (before SEZ establishment) when they still had a negative trade balance of $\$ 484$ million in net imports (Simoes and Hidalgo, 2016). This indicates the country's annual import rate in the global market has been exceeding that of export (Figure 2), a sign that shows that Ghana has less comparative advantage in the world market. The economic complexity ranking of Ghana has decreased by 37 places over the past 50years from $90^{\text {th }}$ in the 60s to $127^{\text {th }}$ as of 2015 (Mehrara, 2013) (Figure 3). Thus Ghana economy particularly in terms of trade and investment does out stand out on the global economic maps.

From above, it seems that Ghana has not taken advantage of the platform SEZ provides as a mechanism to transform export gains and improve competiveness in the global market. Thus, the need to explore Ghana's export comparative advantage patterns and competiveness in the world market for further understanding of progress and propose strategies for the way forward. 


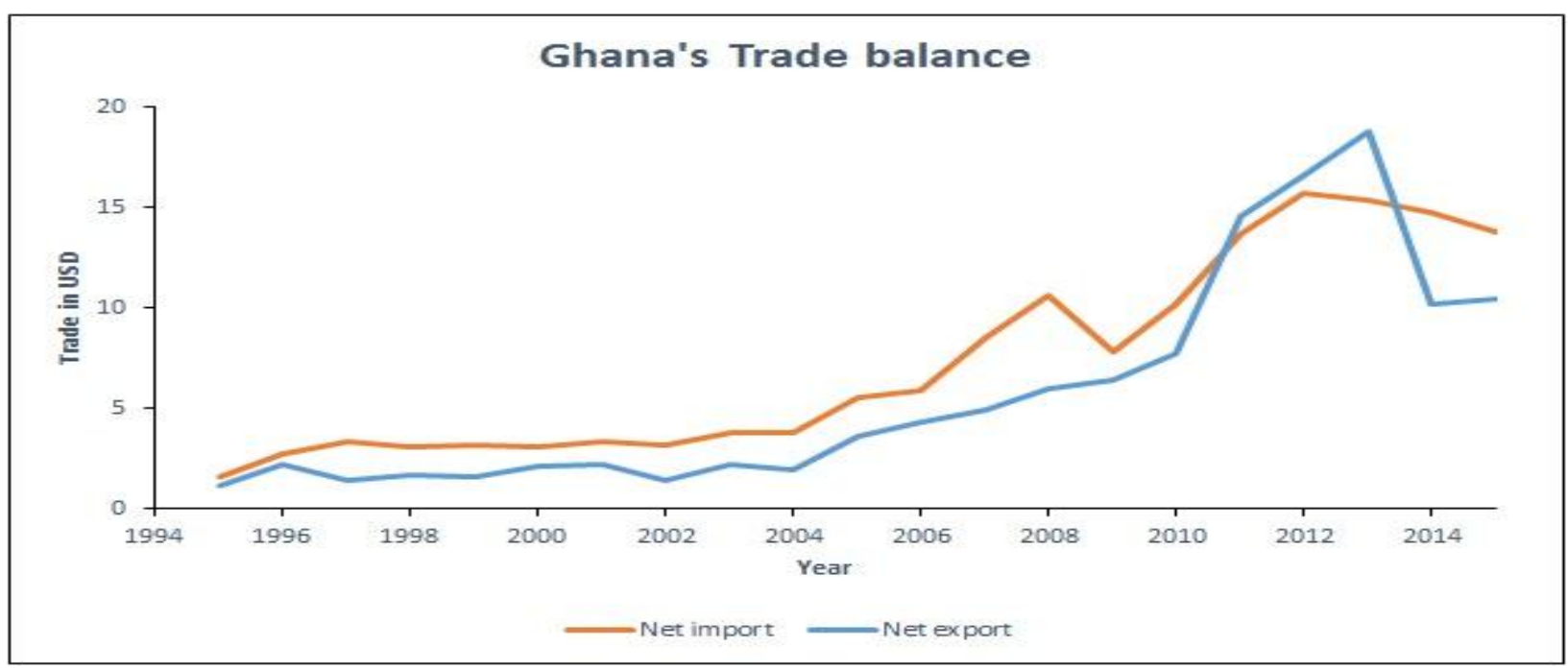

Figure 2. Trade balance for Ghana (1995-2015). Net trade amount is in USD (Billions) Source: The Observatory of Economic Complexity database, compiled by the authors in March 2017

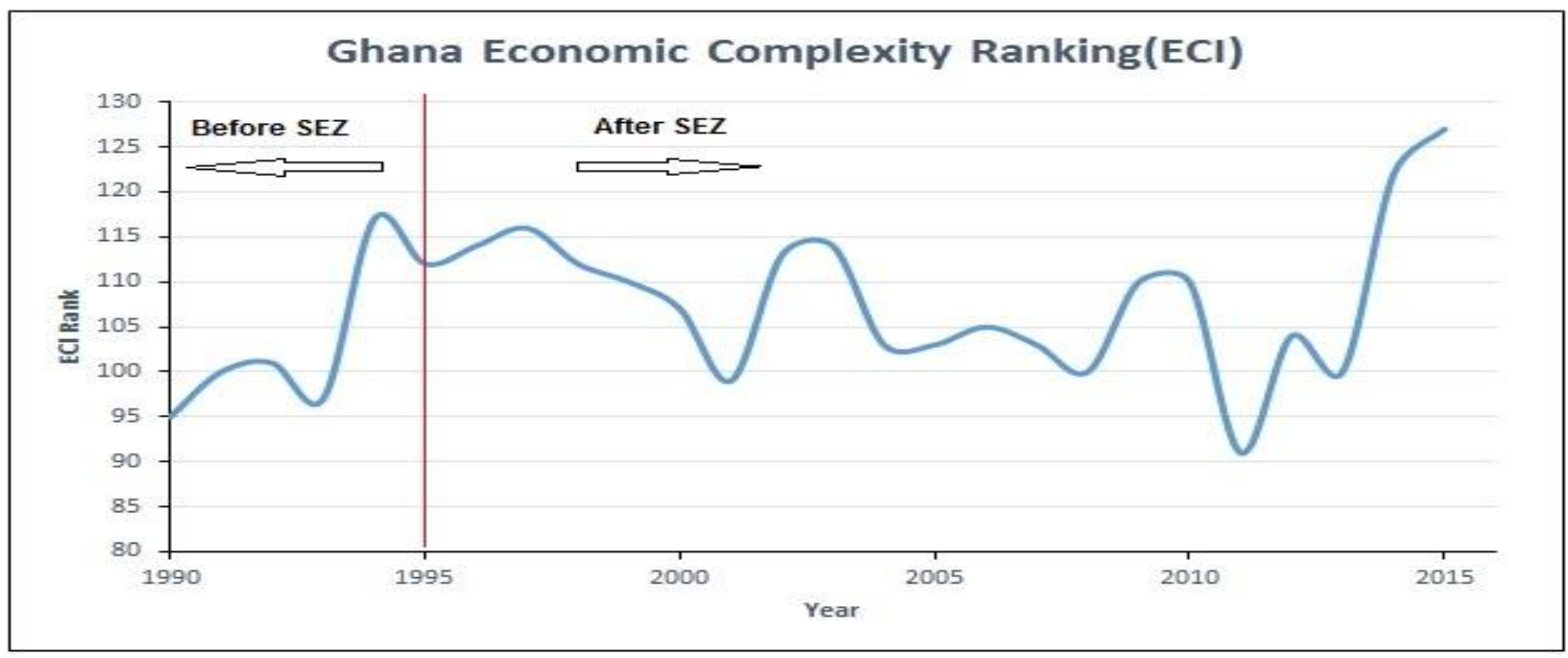

Figure 3. The Economic Complexity ranking of Ghana before and after establishment of free trade zones in 1995

Source: The Atlas of Economic Complexity (online version) database, compiled by the authors in March 2017

\section{Approach and Methods}

\subsection{Study Data}

The data used here for the analysis was sourced from the World Bank - World Integrated Trade Solution database based on SITC between Ghana and China. Data limitations constrain the indices to the year 1996-2013. The analysis thus performed was based on the annual time 
series data of exports of specific products of both Ghana and China. The products investigated were coded and categorized based on the Standard International Trade Classification (SITC) by the World Trade Organization for listing products (Table 1). Data was compiled in MS Excel to estimate and analyze the RCA and R statistical tool was employed to examine the Spearman Rank Correlation Coefficient (R Core Team, 2012).

Table 1. Products investigated in the study and their Standard International Trade Classification (SITC) number as specified by the World Trade Organization for listing products

\begin{tabular}{|c|c|}
\hline SITC & Products \\
\hline 0 & Food products \\
\hline 2 & Wood \\
\hline 3 & Minerals \\
\hline 4 & Animal products \\
\hline $5+6$ & Plastic and rubber \\
\hline 65 & Textiles and clothing \\
\hline 67 & Metals \\
\hline
\end{tabular}

\subsection{The Revealed Comparative Advantage (RCA) Model}

This paper employs the concept of revealed comparative advantage as by Balassa (1965 and 1977). Therefore, it is known as the 'Balassa index' for empirically identifying a country's weak and strong export sectors. It uses the trade pattern to reveal the sectors in which an economy has a comparative advantage by comparing the relative advantage or disadvantage of the said country in a certain class of products with the global trade flow (Balassa, 1977; Bowen, 1983; Greenaway and Milner, 1993). Herein, it is used to examine the relative export performance of selected products in Ghana which will define Ghana's share of the global exports of that product divided by its share of total global exports. The motive for comparison with China is because of the increasing importance of China in global trade as well as the significant trade patterns and differences between China and Ghana.

The Revealed Comparative Advantage (RCA) index has been defined (Balassa, 1965) as follows

$$
\operatorname{RCA}_{\mathrm{ij}}=\frac{\left(\mathrm{X}_{\mathrm{ij}} / \mathrm{X}_{\mathrm{wj}}\right)}{\left(\mathrm{X}_{\mathrm{i}} / \mathrm{X}_{\mathrm{w}}\right)}
$$

where, $\mathrm{RCA}_{\mathrm{ij}}$ is revealed comparative advantage of country $\mathrm{i}$ of product $\mathrm{j}$

$\mathrm{X}_{\mathrm{ij}}$ denotes export of product $\mathrm{j}$ from country $\mathrm{i}$

$\mathrm{X}_{\mathrm{wj}}$ denotes total amount of global exports of product $\mathrm{j}$

$\mathrm{X}_{\mathrm{i}}$ denotes total exports of country $\mathrm{i}$ 
$\mathrm{X}_{\mathrm{W}}$ denotes total amount of world exports

The benefit of using RCA index is that it regards the intrinsic advantage of a particular export product and is coherent with changes in an economy's relative factor endowment and productivity (Sanidas and Shin, 2010, FAO, 2015). However, it cannot separate improvements in factor endowments and pursuit of suitable trade policies by a country.

\subsection{Range of Values for RCA}

The Revealed Comparative Advantage (RCA) index takes values between the range of $-\infty$ to $+\infty$ which could be less, greater or equal to 1 . This has a relatively simple interpretation where ${ }_{\mathrm{RCA}_{\mathrm{ij}}>1}$ means the country $\mathrm{i}$ has comparative advantage in exports of product $\mathrm{j}$ because its market share is larger in the product than its share in total exports. The $\mathrm{RCA}_{\mathrm{ij}}<1$ is explained in the vice versa (Greenaway and Milner, 1993).

RCA indices are a useful measure of competitive performance enabling the identification of specialization patterns (Kaimakoudi et al., 2014; Pilinkiené, 2014; Hidayati and Masyhuri, 2015; Karelakis et. al, 2017). Herein, the RCA index for specific products for exports of Ghana and China is computed. The products investigated were categorized based on the Standard International Trade Classification (SITC) by the World Trade Organization (Table 1).

\subsection{Spearman Rank $\left(r_{s}\right)$ Correlation Coefficient}

In this study, we computed the Spearman Rank $\left(r_{s}\right)$ Correlation Coefficient from the estimated RCA values of each product pair for Ghana and China to examine how competitive or complementary these two nations are. Spearman rank correlation is a non-parametric measure of the monotomic association between two numeric variables (Zar, 1998). The idea of the Spearman Rank used here will check if it is the case that on the global export market, either country is competing for share or is just complementary in the export of that product or there is no relationship at all between the two countries. This approach has been employed in recent time by several studies to explore the degree of competition exhibited by an industry in relation to others and/ or two countries (Mahmood, 2000; Gauthier, 2001; Mohan, 2013; Franco et al., 2014)

Correlation coefficients take the values between minus one and plus one. This means a higher positive values of the coefficient is an indicative of a competitive relationship between Ghana and China in the global export market. Similarly, a negative coefficient implies a complementary in export of the particular product between Ghana and China. There is no relationship if the coefficient value is zero. The Spearman Rank $\left(r_{s}\right)$ coefficient is expressed according to the following equation

$$
r_{s}=1-\frac{6 \Sigma d_{i}^{2}}{n\left(n^{2}-1\right)}
$$


where $\mathrm{d}_{\mathrm{i}}=\mathrm{RCA}(\mathrm{Gh})_{\mathrm{i}}-\mathrm{RCA}(\mathrm{Ch})_{\mathrm{i}}$, and $\mathrm{n}$ is total years under consideration. Here,

$\mathrm{RCA}(\mathrm{Ch})$ and $\mathrm{RCA}(\mathrm{Gh})$ are a set of the RCA values of China and Ghana respectively for a particular product.

Ranking data is carried out on the RCA of the two countries for the product that are separately put in order and are numbered. If the data are correlated, than the sum of the square of the difference between the ranks will be small. The magnitude of the sum is related to the significance of the correlation. The advantage of the Spearman Rank coefficient is that it is a nonparametric technique thus it is not impacted by the population distribution (Zar, 1998).

\section{Results and Discussion}

\subsection{The Comparative Advantage and/or Disadvantage of the Product Categories}

Figures 4 (a) and 4 (g) shows the analyzed results of the RCA of products categories in SITC 1 to 6 between Ghana and China.

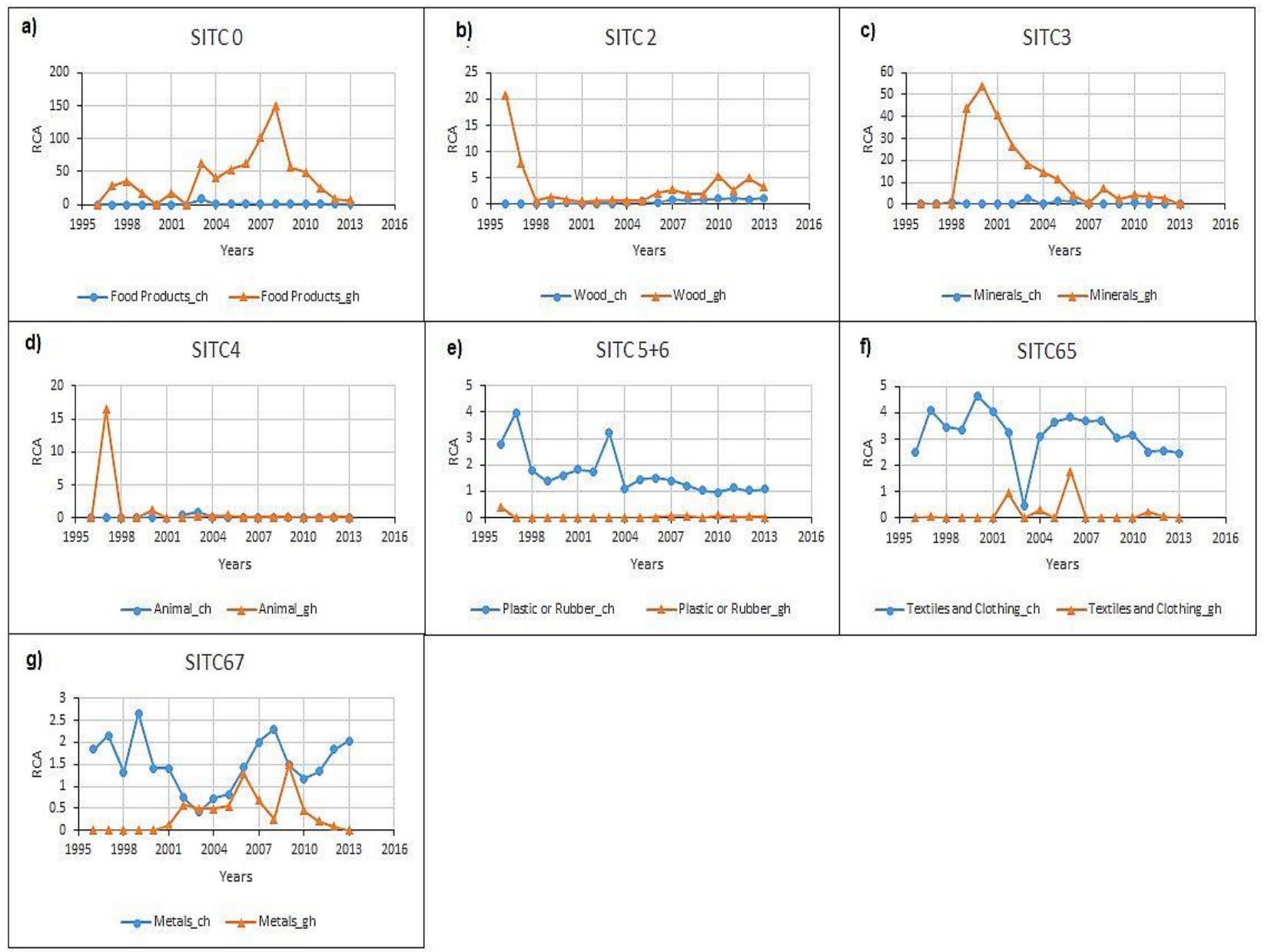

Figure 3. Analyzed results of the revealed comparative advantage (RCA) values for the investigated products for Ghana (gh) and China (ch) 


\subsubsection{SITC 0 - Food Products}

The RCA values of SITC 0 (Food products) from year of 1996 to 2008 is high with an average of 47.65 which peaked at 149.8 in the year 2008 (Fig 4a). This shows that Ghana has a high significant comparative advantage in her export of food products to the world market during those years. However, a sudden decrease was observed from year 2009 and hit lowest of 6.76 in year 2013. On the other hand, the RCA value of SITC 0 for China shows a slim increase, although insignificantly from the year 1997 to 2003 peaking at 8.72 in the year 2003 . Overall, this indicates China's weak comparative advantage of food products in the global market. Accordingly, the gradual declining shift of RCA from 2009 shows Ghana has been losing her comparative advantage. This affirm the recent studies (Lançon and Benz , 2007; Cudjoe et al., 2010) which have asserted that Ghana recently depends on importing food products showing that Ghana is losing grip on being once a powerhouse of food exports to the world. Generally, the comparative analysis of RCA demonstrates that for the product of SITC 0, Ghana whiles currently showing decline in RCA value is positioned more advantageously than China in the world market.

\subsubsection{SITC 2 - Wood}

The RCA value of SITC2 - Wood for Ghana was 20.8 in the year 1996 and its value decreased rapidly from 1997 peaking at 0.64 in the year 2005 (Fig 4b). The RCA value began to pick up again from the year 2001 at 2.1. Since then until 2013, the RCA value for wood in Ghana has fluctuated showing gradual rise and fall. The values from 2007 indicates that Ghana in recent times is having a significant comparative advantage in her export of Wood to the global market. China on the contrary has less comparative advantage in the export of Wood with an average RCA value of 0.52 for the 17years under this investigation compared to the average RCA of 3.34 for Ghana. Overall, comparative analysis of RCA shows that for the product of SITC2, Ghana is positioned more advantageously than China in the world market.

\subsubsection{SITC 3 -Minerals}

The RCA value of SITC 3 -Minerals products for Ghana was 0.05 in the year 1997 where it value quickly jumped to 43.85 in 1999 and peaking at 53.92 in 2000 (Fig 4c). It shows that Ghana at this period (1997-2000) had a strong comparative advantage in the world market. Ghana's levels mineral production particularly gold, diamond and bauxite in to the world market rocketed within this period. This was in the period where Ghana's minerals and mining sector saw a major resurgence contributing massively to the national economy becoming the main foreign exchange earner (Addy, 1998; Aryee, 2001). However, inter-temporal shifts of RCA of SITC 3 during the year 2004 t0 2013 shows that the comparative advantage has decreased significantly. It interprets a significant reversal in Ghana's mineral sector export performance in the world market. This has been attributed to the increase in operational costs and decline in reserves (Amponsah-Tawiah and Dartey-Baah, 2011). Contrarily, the RCA value of SITC 3 was 0.47 in 1996 which indicates China has no comparative advantage of SITC 3 in the world market. Considering inter-temporal shifts of RCA of SITC 3 in China, the analysis indicate that China gained a comparative advantage in 
2003 with RCA value of 2.93. However, a relatively low RCA values compared to Ghana between 2004 to 2013 shows Ghana is positioned more advantageously than China in the world market.

\subsubsection{SITC 4 - Animal Products}

The RCA value of SITC 4 -Animal products for Ghana was 16.42 in the year 1997 where it value decreased to 0.1 in 2013 (Fig 4d). That shows the declining and weak comparative advantage of animal products for Ghana in the world market. In regards to inter-temporal shifts of RCA of SITC 4, it indicates that the comparative advantage has steeply and significantly declined over the years. The case for China is no different to Ghana which shows an overall inter-temporal decreased indicating also a less comparative advantage of export of animal products in the world market. Overall, the analysis shows that for the product of SITC 4, both Ghana and China is positioned less advantageously in the world market.

\subsubsection{SITC 5+6 - Plastic and Rubber}

The RCA value of SITC 5+6 - Plastic and Rubber for Ghana was 0.4 in the year 1996 where its value declined to 0.02 in 2013 (Fig 4e). This shows that Ghana has no significant comparative advantage in her export of Plastic and Rubber to the world market. The inter-temporal shift of RCA during 1996-2013 affirms that Ghana's comparative advantage over plastic and rubber is very insignificant, rather Ghana imports plastic and rubber from other countries particularly China. On the other hand, China had and RCA value of 3.97 in 1997 which indicates China's high comparative advantage over SITC 5+6 in the world market (Fig 4e). However, looking at the inter-temporal shift of RCA during 1997-2013, China has been losing gradually her comparative advantage which declined to 1.07 in 2013 . Overall, the analysis shows that for the product of SITC 5+6, China is positioned more advantageously than Ghana in the world market.

\subsubsection{SITC 65 -Textiles and Clothing}

The RCA value of SITC 65 -Textiles and clothing products for Ghana was 0.07 in the year 1997 where it slightly increased to 1.78 in 2006 and decreased to 0.06 in 2013 (Fig 4f). This shows Ghana has no comparative advantage in the world market for textiles and clothing. This is not surprising though as the textile sector in most Africa countries including Ghana is known to be import dominated (Teal, 2002; Jauch and Traub-Merz, 2006). China's RCA value for SITC 65 was 2.51 in 1993 (Fig 4f) which shows China has relatively high comparative advantage in the world market for Textiles and clothing. Inter-temporal shift analysis however shows China hit a low RCA in 2003 (RCA $=0.47$ ) but steadily increased to high of 3.7 in 2008 and maintaining that till 2013. The textile and clothing industry is known to be a mainstream and key industry in Chin possessing a considerable percentage of the national economy since the reform (Lau et al., 2009) and ranking first in the world in annual production. Overall, the comparative analysis of RCA shows China is positioned advantageously compared to Ghana in the world market for the product of SITC 65. 


\subsection{SITC $67-$ Metals}

Figure $4 \mathrm{~g}$ shows that Ghana has no comparative advantage for SITC 67 in the world market from 1993 to 2001. Inter-temporal analysis however shows that in 2002, Ghana recorded a peak high RCA value of 1.27 but decreased since then. On the contrary, China RCA value in 1993 was 1.84 which peaked at 2.66 in 1999 (Figure 4g). This shows China has relatively high comparative advantage in the world market for metals. China's metal industry particularly steel is recorded to be dominating in the global market (Popescu et al, 2016, Wu et al., 2017). Overall, comparative analysis of the RCA values indicates that for the product of SITC 67, China is placed highly advantageous than Ghana in the global market.

\subsection{Competitive Evaluation of the 7 Products for Ghana and China}

Table 2 shows the level and pattern of competition between Ghana and China in the global market from 1993-2013. This have been assessed by determining the Spearman's Rank Correlation coefficients for the RCA index for both Ghana and China in the products for SITC 0-6 as well as 65 and 67. This was an attempt to key out if Ghana and China compete and/ or complement each other in the world market for the investigated products.

Here, the results was interpreted on a two level scale of competiveness and complementariness where positive $r_{s}$ shows competitiveness between the two countries and negative $r_{s}$ shows complementariness between the two countries for that product. The results reveals higher competiveness for food products and wood (SITC 0 and 2) for the two countries with SITC 0 showing highest level of competiveness. On the hand, $\mathrm{r}_{\mathrm{s}}$ for SITC 3 , $5+6,65$ and 67 indicates that's the two countries are complementary in the world market for Minerals, plastic and rubber, Textiles and clothing and Metals.

Table 2. The calculated Spearman Rank $\left(\mathrm{r}_{\mathrm{s}}\right)$ Correlation Coefficient values of the investigated products between Ghana and China

\begin{tabular}{|c|c|c|}
\hline SITC & Products & $\mathbf{r}_{\mathbf{s}}$ \\
\hline 0 & Food products & 0.63 \\
\hline 2 & Wood & 0.235 \\
\hline 3 & Minerals & -0.164 \\
\hline 4 & Animal products & NA \\
\hline $5+6$ & Plastic and rubber & -0.358 \\
\hline 65 & Textiles and clothing & -0.011 \\
\hline 67 & Metals & -0.387 \\
\hline
\end{tabular}

\section{Conclusions and Recommendations}

This study analyzed the revealed comparative advantage for some products based on the Standard International Trade Classification (SITC) by the World Trade Organization for listing products between Ghana and China. The analysis herein shows that among the investigated 7 products, Ghana is positioned more advantageously in the world market than China over 3 products which includes Minerals, Wood and Food products. Similarly, China 
also had a comparative advantage than China over 4 products including Textiles and clothing, Plastic and rubber, Metals and Animal products. The inter-temporal shifts of RCA over the studied years shows China has improved her comparative advantage over the years for most products whiles Ghana has seen a relative decline in her competiveness in the investigated product. From the results, we can understand that the composition of exports in Ghana shows little and/or low comparative advantage for manufactured goods with maintained competitiveness for raw materials. Apparently, the industrial sector in Ghana is being challenged with the domination of low value added products, the increased imports of manufactured goods, thus industries face competition both in the internal and external markets.

For the time period, Ghana has showcased its high comparative advantage for resource intensive product, likewise traditional primary export namely Raw Materials, Food Products (SITC 0), Minerals (SITC 3) and Wood (SITC 2). The RCA index for Ghana overall indicates that Ghana has not improved its specialization even in the exports of its resource intensive products like Wood (SITC 2), Minerals (SITC 3). In contrast, China shows steady growth in all its high comparative advantage product categories. Clearly, Ghana appears to not have made any substantial progress towards taking advantage of the dynamic potential of SEZs as a tool for sustainable exports gains transformation. From the analysis, it is not surprising why the annual total exports per capita of Ghana (Figure 1) has reduced significantly over the last two decades. A clear indication of how Ghana has lost its competiveness in the world market. Ghana's net exports results have not been consistent, thus averagely on the decline where free zones exports have been less than $10 \%$ of total exports. This could be attributed to the less enduring change in export structure in bare contrast to other successful countries

Based on the revelation from this study, the following recommendations are suggested to overcome these and many more challenges facing Ghana free trade zones

1. There is the need to increase diversification and sophistication of Value Chains. This will not only aim at pushing the industrialization of the country forward but also improve the competitive advantage of the existing sectors for example agriculture sector thus reduce the country's vulnerability in the world market. All stakeholders including policymakers, businesses, Ghana Free Zones Board, Ghana Investment Promotion Centre, financial institutions etc. must have strong and long-term commitment, should be interested in complex production and services processes that could ensure the continuity of SEZ policy with adequate provision of basic services. More so, Ghana can draw some key useful lessons from China's experiences of SEZ program.

2. Learning from China, Ghana could employ an economic shifting from labor intensive industry to technology based industry in their SEZs which is likely to improve efficiency and add value to products to attract world trade market.

3. A fundamental key objective of SEZs is to overcome the constraints of trade and provide better operating environments. Declines in the exports pattern leading to less competiveness could be attributed to the lack of investors to trade in the products. One of the concern of Ghana's SEZ has been the inability to attract foreign direct 
investors to do business with. This is mostly as a result of the weak or lack of institutional authority and administrative procedures characterized by chaotic environment for industries to operate and attract foreign investors and trade partners. In China's SEZ program, the government have laid down formal, empowered one-stop-shops in the zones together with dedicated onsite customs clearance. This was seen to be key to provide an internationally competitive operating environment for investors and trade partners.

4. Finally, further study is required to better improve our understanding on the contributing factors that drives the presented results in this study. This could be by drafting and administering surveys, and direct interview with stakeholders to investigate and come out with more policy level suggestions for improvement.

\section{Acknowledgements}

This study was supported by the Jiangsu Research Planning Project for Philosophy and Social Science project on Study on Strengthening Connection Cooperation with Shanghai Free Trade Zone of Jiangsu Province (Project No. 14SZB028). The authors would like to show their appreciation to $\mathrm{Dr} \mathrm{He}$ (School of Business, Hohai University, China) and other anonymous reviewers for their constructive comments and thorough review of the paper.

\section{References}

Addy, S. N. (1998). Ghana: revival of the mineral sector. Resources Policy, 24(4), 229-239. https://doi.org/10.1016/S0301-4207(98)00035-X

Aggarwal, A., Hoppe, M., \& Walkenhorst, P. (2008). Special Economic Zones in South Asia: Industrial Islands or Vehicles for Diversification?. Retrieved January, 10, 2017.

Amponsah-Tawiah, K., \& Dartey-Baah, K. (2011).The mining industry in Ghana: a blessing or a curse. International Journal of Business and Social Science, 2(12).

Angko, W. (2014). Analysis of the Performance of Export Processing Zones in Ghana. Journal of Business Administration and Education, 5(1), 1.

Aryee, B. N. (2001). Ghana's mining sector: its contribution to the national economy. Resources Policy, 27(2), 61-75. https://doi.org/10.1016/S0301-4207(00)00042-8

Balassa, B. (1965). Trade liberalisation and "revealed" comparative advantage. The Manchester School, 33(2), 99-123. http://dx.doi.org/10.1111/j.1467-9957.1965.tb00050.x

Balassa, B. (1977). 'Revealed'comparative advantage revisited: An analysis of relative export shares of the industrial countries, 1953-1971. The Manchester School, 45(4), 327-344. http://dx.doi.org/10.1111/j.1467-9957.1977.tb00701.x

Balassa, B., \& Noland, M. (1989). The changing comparative advantage of Japan and the United States. Journal of the Japanese and International Economies, 3(2), 174-188. https://doi.org/10.1016/0889-1583(89)90003-8

Bowen, H. P. (1983). On the theoretical interpretation of indices of trade intensity and 
revealed comparative advantage. Weltwirtschaftliches Archiv, 119(3), 464-472.

https://doi.org/10.1007/BF02706520

Chalfin, B. (2001). Border zone trade and the economic boundaries of the state in north-east Ghana. Africa, 71(02), 202-224. https://doi.org/10.3366/afr.2001.71.2.202

Cudjoe, G., Breisinger, C., \& Diao, X. (2010). Local impacts of a global crisis: Food price transmission, consumer welfare and poverty in Ghana. Food Policy, 35(4), 294-302. https://doi.org/10.1016/j.foodpol.2010.01.004

FAO (2015). RCA Indices. Banckok FAO (Food and Agricultural Organization of United Nations).

Farole, T. (2011). Special economic zones in Africa: comparing performance and learning from global experiences: World Bank Publications.

Franco, S., Murciego, A. \& Wilson, J. (2014). Methodology and findings report for correlation analysis between cluster strength and competitiveness indicators. European Cluster Observatory Report

Gautheir, T. D. (2001). Detecting trends using Spearman's rank correlation coefficient. Environmental forensics, 2(4), 359-362.

Greenaway, D. \& Milner, C. (1993). Trade and industrial policy in developing countries: A manual of policy analysis. University of Michigan Press.

Hidayati, S., \& Masyhuri, M. (2015). Analysis of Determinant Indonesian Tuna Fish Competitiveness in Japanese Market. International Journal of Agriculture System, 3(2), 169-178. http://dx.doi.org/10.20956/ijas.v3i2.105

Jauch, H., \& Traub-Merz, R. (2006). The textiles and clothing industry in Ghana.

Kaimakoudi, E., Polymeros, K., \& Batzios, C. (2014). Investigating export performance and competitiveness of Balkan and eastern European fisheries sector. Procedia Economics and Finance, 9, 219-230. https://doi.org/10.1016/S2212-5671(14)00023-9

Karelakis, C., Loizou, E., \& Vladu, M. (2017). Exploring the competitiveness, of the greek fisheries sector. Annals of the University of Craiova-Agriculture, 46(1), 188-198.

Lau, C. K., To, K. M., Zhang, Z., \& Chen, J. (2009). Determinants of competitiveness: Observations in China's textile and apparel industries. China \& World Economy, 17(2), 45-64. https://doi.org/ 10.1111/j.1749-124X.2009.01141.x

Lançon, F., \& Benz, H. D. (2007). Rice imports in West Africa: trade regimes and food policy formulation. In Poster prepared for presentation at the 106 th seminar of the EAAE, 25-27 October 2007, Montpellier.

Leith, J. C. (1996). Ghana, Structural Adjustment Experience. International Center for Economic Growth.

Litwack, J. M., \& Qian, Y. (1998). Balanced or unbalanced development: special economic 
zones as catalysts for transition. Journal of Comparative Economics, 26(1), 117-141. https://doi.org/10.1006/jcec.1997.1502

Mehrara, M. (2013). Ranking of developing countries Based on the Economic Freedom Index. International Letters of Social and Humanistic Sciences, 2, 32-38.

Moberg, L., \& Tarko, V. (2014). Why no Chinese Miracle in Africa? Special Economic Zones and Liberalization Avalanches.

Mohan, K. L. (2013). Analyzing competitiveness of clothing export sector of India and Bangladesh: Dynamic revealed comparative advantage approach. Competitiveness Review: An International Business Journal, 23(2), 131-157.

https://doi.org/10.1108/10595421311305343

Pilinkienè, V. (2014). Evaluation of International Competitiveness Using the Revealed Comparative Advantage Indices: The Case of the Baltic States. Mediterranean Journal of Social Sciences, 5(13), 353. http://dx.doi.org/10.5901/mjss.2014.v5n13p353

Popescu, G. H., Nica, E., Nicolăescu, E. \& Lăzăroiu, G. (2016). China’s steel industry as a driving force for economic growth and international competitiveness. Metalurgija 55(1), 123-126.

Sanidas, E. \& Shin, Y. (2010). Comparison of revealed comparative advantage indices with application to trade tendencies of East Asian countries. In 9th Korea and the World Economy Conference, Incheon, June 25-26.

Simoes, A., \& Hidalgo, C. A. (2016). The observatory of economic complexity.

Söderbom, M., \& Teal, F. (2003). Are manufacturing exports the key to economic success in Africa? Journal of African Economie, 12(1), 1-29. https://doi.org/10.1093/jae/12.1.1

Supongpan, K. K., Dawson, P., \& Lingard, J. (2013). The export competitiveness of the tuna industry in Thailand. British Food Journal, 115(3), 328-341.

https://doi.org/10.1108/00070701311314174

Team, R. C. (2012). R: A Language and Environment for Statistical Computing. Vienna: R Foundation for Statistical Computing..

Wu, H., Lv, K., Liang, L., \& Hu, H. (2017). Measuring performance of sustainable manufacturing with recyclable wastes: A case from China's iron and steel industry. Omega, 66, 38-47. https://doi.org/10.1016/j.omega.2016.01.009

Zar, J. H. (1998). Spearman rank correlation. Encyclopedia of Biostatistics.

Zeng, D. Z. (2015). Global experiences with special economic zones: focus on China and Africa. Policy Research Working Paper 7240 


\section{Copyright Disclaimer}

Copyright for this article is retained by the author(s), with first publication rights granted to the journal.

This is an open-access article distributed under the terms and conditions of the Creative Commons Attribution license (http://creativecommons.org/licenses/by/3.0/). 